\title{
Kurikulum Pendidikan Agama Kristen Yang Kontekstual Bagi Anak Sekolah Minggu Kelas Madya
}

\author{
Wiwiet Arie Shanty \\ Mahasiswa Program Pascasarjana Magister Pendidikan Agama Kristen Sekolah Tinggi \\ Teologi Real Batam \\ Email:wiwietarieshanty@gmail.com \\ Talizaro Tafonao \\ Dosen Pascasarjana Pendidikan Agama Kristen Sekolah Tinggi Teologi Real Batam \\ Email: talizarotafonao@gmail.com \\ Desetina Harefa \\ Dosen Prodi PAUD Sekolah Tinggi Teologi Real Batam \\ Email: desetina.harefa@gmail.com
}

\begin{abstract}
This paper is a study of the Sunday school curriculum in the church, especially the middle class. Sunday School cannot be separated from the church as a forum for evangelism and teaching about Christian Religious Education. So far, there are still many churches that have not given serious attention to preparing the Sunday School curriculum. Therefore, the purpose of writing this article is to encourage churches and teachers to prepare a curriculum that is in accordance with the characteristics of middle graders. The method used is a library research method, which examines a contextual Christian religious education curriculum for middle class Sunday schools. The analysis process carried out by the author is to use a variety of trusted electronic and library sources to support the author's analysis. The results obtained in this study are the importance of understanding the nature of Sunday school, the characteristics of middle school children, the appropriate Sunday school curriculum and the involvement of Sunday school teachers. Seeing this, the Christian religious education curriculum in middle class is very urgent to be prepared and paid attention to by the church today based on the needs of Sunday school children.
\end{abstract}

Keywords: curriculum; christian education; middle children; characteristics; sunday school

\section{Abstrak}

Tulisan ini merupakan kajian terhadap kurikulum sekolah minggu di gereja terutama kelas madya. Sekolah Minggu tidak bisa lepas dari gereja sebagai wadah penginjilan dan pengajaran tentang Pendidikan Agama Kristen. Selama ini masih banyak gereja yang belum memberi perhatian serius dalam mempersiapakan kurikulum anak Sekolah Minggu. Oleh karena itu, tujuan penulisan artikel ini adalah mendorong gereja dan guru untuk mempersiapkan kurikulum yang sesuai dengan karakteristik anak kelas madya. Metode digunakan adalah metode penelitian pustaka, yang mengkaji kurikulum pendidikan agama Kristen yang kontekstual bagi sekolah minggu kelas madya. Proses analisis yang dilakukan oleh penulis adalah menggunakan berbagai sumber pustaka maupun elektronik yang terpercaya untuk mendukung analisis. Hasil yang didapatkan dalam kajian ini adalah pentingnya memahami hakikat sekolah minggu, karakteristik anak madya, kurikulum sekolah minggu yang sesuai dan keterlibatan guru sekolah minggu. Dengan melihat hal tersebut maka kurikulum pendidikan agama Kristen di kelas madya merupakan hal yang sangat urgen untuk dipersiapkan dan perhatikan oleh gereja saat ini berdasarkan kebutuhan anak-anak sekolah minggu.

Kata kunci: kurikulum; pendidikan kristen; anak madya; karakteristik; sekolah minggu 


\section{Pendahuluan}

Gereja sebagai wadah penginjilan dan pengajaran tentang Pendidikan Agama Kristen kepada setiap jemaat dan anak-anak, termasuk sekolah minggu sebagai wadah pengajaran bagi anak-anak. Inilah salah satu fungsi dari gereja selain ibadah, persekutuan, pengajaran, misi, dan pelayanan pastoral. Dalam Firman-Nya di Markus 10:14, “biarkan anak-anak itu datang kepada-Ku, jangan menghalang- halangi mereka, sebab orang-orang seperti itulah yang empunya kerajaan Allah" dengan pernyataan ini membuktikan bahwa gereja mengemban amanat agung untuk memberitakan kebenaran bukan saja kepada orang dewasa namun juga anak-anak. ${ }^{1}$ Dengan latar belakang inilah sekolah minggu yang menjadi sebagai wadah pengajaran bagi anakanak di lembaga gereja mempunyai peran penting di dalam memberikan pendidikan agama Kristen untuk mengenalkan Tuhan Yesus sejak masih usia anak-anak. Selama ini menurut pengamatan peneliti, sekolah minggu dikelola oleh gereja dengan 'apa adanya' dalam arti dengan segala keterbatasan sumber daya manusia dan fasilitas yang ada, anak-anak diberikan pengajaran tentang Firman Tuhan tanpa adanya pembekalan atau dasar Firman Tuhan yang lebih kepada guru-guru Sekolah Minggu. Menurut Yenni Anita Pattinama, banyaknya tantangan dan kemajuan jaman tidak membuat gereja mundur namun semakin mengalami pertumbuhan, demikian juga dengan sekolah minggu yang memberikan dampak pertumbuhan kepada gereja, khususnya anak-anak sebagai generasi muda penerus gereja. Berdasarkan penyataan Riggs bahwa jemaat akan menjadi semakin kuat dan dewasa dalam rohaninya karena pelayanan di bidang anak-anak atau sekolah minggu sungguh-sungguh dikembangkan. Hal ini dikarenakan dari mulai kecil anak-anak ini dididik, dibina dan dibekali dalam sekolah minggu mereka ini bertumbuh rohaninya dan membawa dampak yang positif bagi gereja dan masa depan mereka sendiri. Demikian juga berdasarkan penyataan Laufer bahwa ketika dari masa anak-anak diberikan dasar rohani melalui pendidikan dan pembinaan yang benar, mereka akan mempunyai dasar yang kuat sebagai pegangan dan penopang dalam masa depan mereka. ${ }^{2}$

Dengan memperhatikan hal teresebut di atas, gereja menyesuaikan diri di masa pandemi terutama dalam proses pembelajaran yang dilakukan kepada anak Sekolah Minggu. Artinya bahwa sekolah minggu mengalami perkembangan dan perubahan seperti sekarang ini dimana gereja harus menyesuaikan diri terutama saat pandemi berlangsung. Biasanya pertemuan sekolah minggu dilakukan secara tatap muka sekarang bisa dilakukan melalui online. Tugas gereja untuk tetap memberikan pendidikan Agama Kristen kepada anak-anak harus dilanjutkan. Karena itu kurikulum sekolah minggu harus disesuaikan berdasarkan kondisi yang terjadi pada

1 Yenny Anita Pattinama, "Peranan Sekolah Minggu Dalam Pertumbuhan Gereja," SCRIPTA:

Jurnal Teologi dan Pelayanan Kontekstual 8, no. 2 (2020): 132-151.

2 Ibid. 
masa kini. Dalam penelitian yang dilakukan oleh Karnawati bahwa salah satu tanggung jawab gereja dalam memberi layanan kepada anak sekolah minggu di masa pandemi adalah memberikan ide atau usul mengenai sebuah proyek untuk menguatkan kemampuan orang tua dalam pengetahuan Alkitab dan melatih kemampuan untuk mengajar anak-anak di rumah. ${ }^{3}$ Selain itu, gereja harus memanfaatkan kemajuan teknologi digital sebagai media dalam mendidik kebutuhan rohani bagi anak-anak sekolah minggu dengan memberdayakan guru-guru yang ada.

Anak madya atau anak sekolah minggu usia 9 sampai 11 tahun adalah anakanak pra remaja yang masih terpengaruh dengan kemajuan jaman terutama dengan kemajuan teknologi digital. Sekolah minggu sebagai salah satu wadah untuk memberikan pendidikan agama Kristen selain di sekolah dan keluarga, harus memberikan pengajaran yang tepat dan sesuai dengan kondisi anak madya. Banyak penelitian sebelumnya yang membahas mengenai Kurikulum pendidikan Agama Kristen yang kontekstual bagi anak sekolah minggu kelas madya. Salah satunya adalah tulisan Hutapea pentingnya kreativitas guru sekolah minggu, yang memberikan penjelasan tentang pentingnya kreativitas guru pendidikan agama Kristen dan faktor yang mempengaruhi kreativitas guru dalam mengajar di masa pandemi. ${ }^{4}$ Ada juga penelitian Handreas Hartono mengenai Kurikulum Pendidikan Agama Kristen yang Kontekstual Bagi Usia Lanjut dan Aktual, yang menjelaskan bahwa kurikulum harus bersifat sederhana dan tepat guna yang meliputi pokokpokok iman kristen pendalaman Alkitab dan pendalaman yang efektif. ${ }^{5}$ Selanjutnya penelitian Adolf Edwin Ratag "Pengembangan Kurikulum Sekolah Minggu, yang menjelaskan bahwa mengembangkan atau menyusun kurikulum Sekolah Minggu sangat penting. Kepentingannya semata-mata berkaitan erat dengan peserta didik itu sendiri. ${ }^{6}$ Kajian-kajian yang ada ini lebih banyak menuliskan dari sisi kreativitas guru saja namun belum menjelaskan tentang kurikulum yang sesuai dengan usianya.

Dengan mengamati penjelasan para peneliti di atas, maka penulis mengkaji tulisan ini untuk memberi suatu pemahaman bahwa untuk mengajar sekolah minggu kelas madya sangat diperlukan kurikulum yang tepat. Kurikulum untuk anak sekolah minggu yang berlangsung selama ini belum mempunyai ketetapan yang baku untuk setiap jenjang usia, hal ini lah yang membuat pembelajaran di dalam kelas madya belum maksimal. Selain itu, setiap denominasi gereja mempunyai hak untuk menentukan kurikulum sekolah minggu berdasarkan visi dan misi gereja tersebut.

\footnotetext{
${ }^{3}$ Karnawati Karnawati and Ayin Claudia, "Model Desain Kurikulum Pewartaan Injil Untuk Anak Usia Dini Di Sekolah Minggu Rumah," Integritas: Jurnal Teologi 3, no. 1 (2021): 201-212.

${ }^{4}$ Rinto Hasiholan Hutapea, "Kreativitas Mengajar Guru Pendidikan Agama Kristen Di Masa Covid-19," Didaché:Journal of Christian Education 1 (2020).

${ }^{5}$ Handreas Hartono, "Kurikulum PAK Yang Kontekstual Bagi Usia Lanjut Dan Aktual," Kurios 1 , no. 1 (2018): 11.

${ }^{6}$ Adolf Edwin Ratag, "Pengembanganan Kurikulum Sekolah Minggu," LOGON ZOES: Jurnal Teologi, Sosial dan Budaya 1, no. 1 (2017): 1-17.
} 
Berdasarkan penjelasan tersebut maka dapat disimpulkan bahwa belum adanya kurikulum yang standar atau baku bagi sekolah minggu pada setiap jenjang usianya.

Selain kurikulum yang tepat diperlukan juga sumber daya manusia yang benar-benar mumpuni yaitu guru sekolah minggu yang benar-benar berkompeten dalam bidangnya sesuai dengan firman Tuhan. Fungsi guru disini bukan saja sebagai pengajar atau menyampaikan materi namun juga sebagai konselor bagi anak-anak madya. Menurut hemat Sriyanti dan Nakamnanu, masyarakat memiliki pandangan bahwa orang yang melaksanakan pendidikan di sekolah adalah guru. Sebenarnya pandangan ini tidak selalu benar karena pendidikan dapat dilaksanakan di manapun seperti di rumah, di gereja dan di tempat lain selain di tempat formal yaitu sekolah. ${ }^{7}$ Oleh karena itu, tujuan penulisan artikel ini adalah mendorong gereja dan guru untuk mempersiapkan kurikulum yang sesuai dengan karakteristik anak kelas madya.

\section{Metode}

Metode yang digunakan penelitian adalah kulitatif deskriptif. Menurut Junaidi penelitian kualitatif lebih menekankan pada kualitif atau hal terpenting. Hal terpenting yang dimaksud adalah makna di balik suatu kejadian, fenomena, dan gejala sosial yang dapat dijadikan sebagai pembelajaran berharga bagi pengembangan konsep teori. Penelitian ini bertujuan mendorong gereja dan guru untuk mempersiapkan kurikulum yang sesuai dengan karakteristik anak kelas madya. Peneliti memperoleh data melalui studi pustaka, data empiris dan menelusuri karya ilmiah para peneliti sebelumnya yang telah dipublikasikan terkait tema kajian. Dengan menggunakan kepustakaan, peneliti mengumpulkan data melalui kajian terhadap jurnal, artikel, buku-buku dan karya ilmiah yang dapat dipercaya. Kemudian peneliti menganalisis data dan mendeskripsikan melalui teknik analisis data dengan beberapa tahan, yakni mereduksi data, meng-klasifikasikan dan memvervikasi data berkaitan dengan kajian terhadap artikel ini.

\section{Hasil dan Pembahasan \\ Hakekat sekolah minggu dan Pendidikan Agama Kristen}

Berdasarkan tulisan pada Alkitab Sabda bahwa hakekat sekolah minggu terdapat dalam Firman Tuhan pada Mat. 19:14, “Biarkanlah anak-anak itu, janganlah menghalang-halangi mereka datang kepada-Ku, sebab orang-orang yang seperti itulah yang empunya Kerajaan Surga," Inilah pernyataan Yesus yang sering ditafsirkan bahwa sikap sebagai seorang anak kecil yaitu penuh kejujuran, kerendahan hati, keterbukaan saat datang menghampiri dan penyerahan diri kepada Tuhan Yesus adalah sikap seseorang yang benar di hadapan Tuhan. Hal ini juga

${ }^{7}$ Sriyanti and Esen Hon Nakamnanu, "Peran Guru Dalam Menerapkan Pendidikan Agama Kristen Untuk Menumbuhkan Iman Kristen Anak Sejak Dini," Shamayim 1, no. 1 (2020). 
berdasarkan pada Firman Tuhan dalam Mat. 18:3-4 penafsiran ini memang tepat. Lebih dari itu, sesungguhnya ada beberapa pengajaran yang penting dalam Mat. 19:14 yaitu: a) Allah menghendaki anak-anak itu datang kepada-Nya dan Dia sangat mengasihi mereka. b) Allah memerintahkan bahwa tidak ada seorang pun yang menghalangi dan membuat kesulitan bagi anak-anak untuk datang kepada Dia. c) Orang dewasa harus menolong agar anak-anak mudah datang kepada Tuhan tanpa suatu halangan. d) Seorang anak dihargai sama seperti Tuhan menghargai seorang dewasa. e) Seorang dewasa harus memiliki sesuatu yang indah pada seorang anak dalam hubungan pribadi nya dengan Tuhan, itulah yang Tuhan ajarkan.

Tuhan Yesus memberikan perintah untuk mengadakan pelayanan khusus bagi anak-anak untuk menolong mereka datang kepada Tuhan. Tuhan juga menyediakan waktu khusus untuk melayani anak-anak walaupun Dia sibuk melayani orang dewasa. Tidak ada sikap meremehkan bahkan Tuhan ingin memberkati anak-anak, dan inilah kehendak Tuhan kepada murid-murid-Nya dan kepada gereja sampai hari ini. Robert Rikes menangkap kehendak Tuhan dengan tepat, disaat semua orang tidak mempedulikan nasib anak-anak dan para remaja yang tidak dipedulikan oleh sekitar dan di cap nakal, dia menunjukkan sikap mengerti dan menghayati panggilan pelayanan anak-anak ini. Robert Rikes melayani dan membimbing anak-anak ini dengan penuh pengabdian dan kasih mengajarkan tentang kebenaran Firman Tuhan melalui Alkitab, setiap hari Minggu dia membimbing anak-anak ini kembali ke jalan yang benar. Karena Robert Rikes mempunyai ketekunan dan kegigihan serta visi yang jelas, akhirnya kelompok yang dulunya adalah anak-anak nakal menjadi kelompok murid Yesus. ${ }^{8}$ Inilah kisah kelahiran sekolah Minggu yang pertama di dunia, yaitu di negara Inggris di salah satu distrik di Gloucester (abad ke 18). ${ }^{9}$

Sekolah minggu Anak, merupakan salah satu wujud pelayanan khusus di antara anak-anak dengan tujuan membawa mereka untuk mengenal dan menerima Yesus Kristus sebagai Tuhan dan Juruselamat mereka secara pribadi. Sekolah minggu mempunyai peran yang besar bagi pertumbuhan gereja dan merupakan kesalahan jikalau kita berpikir bahwa sekolah minggu adalah sekedar aktivitas untuk anak-anak pada hari Minggu atau kegiatan mengumpulkan anak-anak jemaat agar tidak mengganggu jalannya ibadah umum. Sekolah minggu mempunyai arti lebih bagi gereja yaitu : 1) Sebuah wadah pembinaan iman dan program pendidikan rohani yang bersifat melaksanakan misi yang ditetapkan Tuhan Yesus Kristus kepada gereja-Nya. Dengan tujuan membawa anak-anak kepada pengenalan yang benar akan Tuhan dan membimbing anak-anak kepada iman yang dewasa di dalam Tuhan Yesus. Gereja tidak boleh puas jikalau jumlah anak dan guru sekolah minggu dalam jumlah yang

8 "Robert Raikers," Wikipedia, accessed October 30, 2021,

https://id.wikipedia.org/wiki/Robert_Raikes.

9 "Hakekat Sekolah Minggu," Alkitab Sabda, accessed May 29, 2021, https://alkitab.sabda.org/. 
besar karena bukan jaminan semua anak ketika sudah remaja dan dewasa menjadi anak Tuhan yang sungguh-sungguh mengasihi Tuhan bahkan mereka banyak yang 'terhilang' dalam dunia ini. Karena itu dituntut guru sekolah minggu yang benarbenar mengasihi dan mengenal kebenaran Firman Tuhan dengan benar, bukan hanya sekedar kerinduan untuk melayani atau sukarelawan. Gereja harus memberikan perhatian yang lebih sungguh-sungguh terhadap pelayanan sekolah minggu karena pertumbuhan gereja secara kuantitatif terlihat dari perkembangan Sekolah Minggu. 2) Sekolah minggu sebagai "ayah dan ibu asuh rohani". Kemajuan teknologi terutama perkembangan alat komunikasi yang sekarang ini hampir semua orang dan segala bidang memerlukannya tidak menutup kemungkinan anak-anak bahkan balita mendapatkan informasi yang tidak sesuai dengan usianya. Segala macam program menarik seperti game atau permainan yang menarik sangat mengikat hati anak dan membuat nya lupa waktu mengakibatkan komunikasi dengan orang tua sangat berkurang. Ditambah dengan tuntutan tugas dan pekerjaan dari sekolah yang sampai saat ini masih menggunakan daring terutama bagi anak-anak madya. Kebutuhan dan pendidikan rohani kurang diperhatikan karena tergeser dengan permainan dan tugas serta program menarik lainnya. Orang tua yang sibuk dalam pekerjaan dengan situasi yang sekarang ini terjadi membuat mereka terlupa untuk memberikan kebutuhan rohani kepada anak-anak. Hal-hal inilah yang membuat banyak keluarga Kristen tidak dapat memberikan pendidikan Kristen kepada anak-anak nya sendiri namun menyerahkan kepada gereja melalui Sekolah Minggu. Kita dapat membayangkan jikalau gereja tidak memandang sekolah minggu sebagai pelayanan yang penting, demikian juga dengan pemilihan guru sekolah minggu yang 'apa adanya' dalam arti tidak ada pelatihan atau pembekalan sebagai guru Sekolah Minggu, tugas yang maha penting ini menjadi hal yang biasa. 3) Gereja di masa datang di tentukan sekolah minggu hari ini. Keadaan sekolah minggu hari ini akan menentukan keadaan gereja di masa yang akan datang. Dari sekolah minggu inilah diharapkan menghasilkan murid-murid Yesus Kristus yang sejati dan mempunyai dedikasi tinggi sehingga menjadi jemaat yang dewasa secara rohani dan menghasilkan buah dalam arti pengembangan gereja pada waktu-waktu mendatang. Gereja diutus Tuhan Yesus ke dalam dunia ini untuk melaksanakan misi agung-Nya yaitu menyinarkan terang Injil pada dunia yang gelap karena di bawah kuasa dosa. 4) Sekolah Minggu sebagai ladang penginjilan. Seorang anak apabila menyerahkan hidupnya untuk Tuhan, artinya seumur hidupnya dipakai untuk berbakti dan melayani Tuhan. 5) Peran sekolah minggu yang sangat penting bagi pertumbuhan gereja. Anak-anak bisa menjadi saksi bagi orang tua dan teman-temannya, bahkan banyak keluarga Kristen dimenangkan dari anak Sekolah Minggu. Karena itu pelayanan sekolah minggu mempunyai peranan besar untuk pertumbuhan gereja. ${ }^{10}$

${ }^{10}$ Ibid. 
Dengan memperhatikan penjelasan sebelumnya, sekolah minggu menjadi wadah bagi gereja untuk memberikan Pendidikan Agama Kristen bagi anak-anak. Menurut Tafonao pengajaran Pendidikan Agama Kristen adalah mengenai hubungan manusia dengan Tuhan dan dapat dilakukan di dalam keluarga, sekolah dan tempat ibadah tanpa dibatasi apapun. ${ }^{11}$ Sedangkan Pendidikan Agama Kristen menurut E.G. Homrighausen mengatakan bahwa "Pendidikan Agama Kristen berpangkal pada persekutuan umat Tuhan. Dalam Perjanjian Lama pada hakekatnya dasar-dasar terdapat pada sejarah suci purbakala, bahwa Pendidikan Agama Kristen itu mulai sejak terpanggilnya Abraham menjadi nenek moyang umat pilihan Tuhan, bahkan bertumpu pada Allah sendiri karena Allah menjadi peserta didik bagi umat-Nya."12 Sedangkan dalam Perjanjian Lama sumber dasar pendidikan adalah Firman Tuhan yang disampaikan langsung pada pengajar yaitu Nabi, ahli taurat dan orang tua. Peran penting dari Pendidikan Agama Kristen adalah mendidik dan mengajar berdasarkan Firman Tuhan namun harus tetap disesuaikan dengan kebutuhan manusia agar dapat memahami dan menghayati nilai-nilai yang terkandung di dalamnya dan dapat melakukannya dalam kehidupan sehari-hari baik melalui percakapan dengan orang lain maupun dengan media sosial. Sedangkan dalam Perjanjian Baru semua bagian dalam kitab memiliki tujuan untuk mengajar umat Kristen tentang Allah dalam Yesus Kristus dan pengaruhnya bagi manusia. ${ }^{13}$ Dari penjelasan di atas dapat disimpulkan bahwa dasar dari Pendidikan Agama Kristen adalah Firman Tuhan sebagai sumber utama.

\section{Karakteristik Anak Madya}

Anak usia 9-11 tahun atau sering disebut anak kelas madya adalah anak pra remaja karena mereka mengalami masa-masa pubertas yaitu proses perubahan fisik, kognitif bahkan sosial emosional. Di masa inilah anak-anak ini mencari identitas diri dengan cara meniru orang lain yang dianggapnya idola, tertarik dengan hal-hal yang bersifat superhero, pusat perhatian dan memakai media sosial untuk menunjukkan siapa dirinya.

Menurut Wijarnarko Utomo dalam tulisannya di Children Café ada empat ciri anak usia 9-11 tahun yaitu: (a) ciri-ciri fisik. Fisik yang semakin baik dan kuat termasuk kemampuan motorik halusnya juga berkembang, koordinasi dan keseimbangan

11 Talizaro Tafonao, “Peran Pengajaran Pendidikan Agama Kristen Dalam Keluarga Sangat Penting Untuk Diajarkan Kepada Anak-Anak, Baik Dalam Keluarga, Sekolah, Di Tempat Ibadah Dan Masyarakat, Agar Kelak Anak-Anak Dapat Menghadapi Setiap Problem Secara Kognitif, Afektif Dan Psik," Edudikara: Jurnal Pendidikan dan Pembelajaran 3, no. 2 (2018): 125.

12 E.G.Homrighausen and I.H.Enklaar, Pendidikan Agama Kristen, 9th ed. (Kwitang, Jakarta: BPK Gunung Mulia, 1987).

13 Talizaro Tafonao and Prasetyo Yuliyanto, "Peran Pendidikan Agama Kristen Dalam Memerangi Berita Hoaks Di Media Sosial," Jurnal Ilmiah Religiosity Entity Humanity (JIREH) 2, no. 1 (2020): 1-12. 
tubuh semakin baik serta aktif dan banyak energi. (b) mental dan intelektual. Salah satu ciri mental dan intelektual yang baik pada anak adalah memiliki kemandirian dalam arti tidak terlalu bergantung pada keluarga dan menekuni apa yang menjadi hobinya, serta daya kreativitasnya sangat tinggi. (c) emosi. Salah satu ciri emosi yang nampak dari anak madya adalah mencari idola dari figur orang dewasa di sekitarnya, suka menutupi perasaan dan berpura-pura tidak ada masalah yang mengganggunya serta tidak suka dibanding-bandingkan. (d) sosial. Salah satu ciri sosial anak madya adalah suka bergaul dengan teman sebaya atau seumuran dengannya dan memiliki solidaritas yang tinggi dengan kelompoknya dan merasa istimewa dengan kelompoknya seperti mempunyai kode dan bahasa sendiri di dalam kelompoknya. ${ }^{14}$

Penulis percaya bahwa karakter yang dimiliki oleh setiap anak madya adalah salah satu fase yang harus dilewati setiap anak, namun perlu juga diketahui bahwa anak-anak tersebut perlu adanya pendampingan terus menerus agar tidak terjadi penyimpangan dalam diri anak tersebut seperti yang dipertontonkan melalui media sosial. Perdana mengusulkan supaya penanaman nilai-nilai karakter bagi anak-anak madya selalu dilakukan melalui keteladanan. ${ }^{15}$

\section{Kurikulum sekolah minggu untuk Anak Madya}

Setelah membaca penjelasan di atas tentang karakteristik anak madya, kurikulum sekolah minggu harus dibuat dan disesuaikan dengan kebutuhan dari anak madya yang secara garis besar adalah anak-anak yang berkembang dengan cepat dari segala aspek baik fisik dan psikologinya. Pada awal bukunya yang berjudul "Mengajar sekolah minggu yang Kreatif" Paulus Lie memberikan masukan yang sederhana demikian bahwa yang paling utama dalam mengembangkan sekolah minggu adalah mengupayakan agar setiap acara sekolah minggu selalu menarik! 16 Hal ini lah yang menjadi alasan sekolah minggu harus menjadi acara yang dinamis, kreatif dan sesuai dengan dunia anak-anak masa kini. Atas dasar penjelasan itulah maka guru sekolah minggu harus mengembangkan kurikulum sekolah minggu tetapi tidak terjebak dalam 'kekakuan' teori-teori pengembangan kurikulum, dengan tidak mengabaikan hal-hal yang terkait dengan konteks dunia anak-anak.

Kata kurikulum berasal dari bahasa Latin currere, yang berarti lapangan perlombaan lari. Kurikulum juga bisa berasal dari kata curriculum yang berarti a

${ }^{14}$ Wijanarko Utomo, “CIRI KHAS PERKEMBANGAN ANAK USIA 9-11 TAHUN," Children Cafe, last modified 2018, accessed May 25, 2021, https:/ / www.childrencafe.com/ciri-khasperkembangan-anak-usia-9-11-tahun/\#: :text=Kini mereka tidak terlalu suka,serta gemar akan berbagai bacaan.

${ }^{15}$ Novrian Satria Perdana, "Implementasi Peranan Ekosistem Pendidikan Dalam Penguatan Pendidikan Karakter Peserta Didik," Refleksi Edukatika: Jurnal Ilmiah Kependidikan 8, no. 2 (2018): 183191.

${ }^{16}$ Adolf Edwin Ratag, "Pengembanganan Kurikulum Sekolah Minggu," LOGON ZOES: Jurnal Teologi, Sosial dan Budaya 1, no. 1 (2017): 1-17. 
running course, dan dalam bahasa Prancis dikenal dengan carter berarti to run (berlari). ${ }^{17}$ Menurut Hilda Taba, dengan mempertimbangkan berbagai macam hal proses pembelajaran dan perkembangan individu disusunlah rancangan pembelajaran yang disebut dengan kurikulum. ${ }^{18}$ Enklaar dan Homrighausen menjelaskan bahwa istilah curriculum pada dasarnya berarti lapangan perlombaan, di mana penekanannya, yaitu seperti sebuah perlombaan ada titik tertentu untuk mulai dan ada titik tertentu untuk berakhir. Dalam artian bahwa kurikulum adalah suatu proses perjalanan dari permulaan sampai tamat dijalani sebagai suatu perjalanan yang lengkap dan teratur. ${ }^{19}$ Berdasarkan pendapat dan penjelasan di atas dapat disimpulkan bahwa kurikulum sekolah minggu adalah perencanaan pembelajaran yang disusun dengan tujuan menjadikan murid Kristus yang terdapat pada Mat. 28:18-20 serta tumbuh dewasa dalam Kristus tertulis dalam Ef. 4:11-15 semuanya didasarkan pada Alkitab. ${ }^{20} \mathrm{Hal}$ ini tugas yang disampaikan oleh Simanjuntak dan Tafonao Kurikulum pendidikan Kristen memiliki muatan yaitu proses pengajaran dan pembelajaran yang dibangun berdasarkan Alkitab serta berpusat pada Kristus, dan bergantung pimpinan Roh Kudus. ${ }^{21}$

Pada awalnya kurikulum sekolah minggu juga mengalami perkembangan dari masa ke masanya yaitu dari awal terbentuknya sekolah minggu pada tahun 1780 sampai sekarang gereja terus memperbaharui akan kurikulum Sekolah minggu agar dapat tercapai pada tujuan nya. Oleh karena itu, kurikulum Sekolah Minggu harus disusun sekaligus disesuaikan dengan konteks anak madya usia 9-11 tahun. Berdasarkan karakteristik anak madya yang sudah dijelaskan di atas, di bawah ini ada beberapa contoh bahan materi pelajaran dan aktivitas untuk kurikulum kelas madya yang dapat dilakukan baik dengan tatap muka maupun online dengan sistem pembagian kelompok seperti pemakaian zoom dengan teknis breakout room, bisa dengan Video Call melalui WhatsApp Grup, dan guru tetap bisa memantau dengan masuk dalam aplikasi yang sudah ditentukan sebagai berikut:

17 Siti Anisatun Nafi'ah, “Model Pengembangan Kurikulum Hilda Taba Pada Kurikulum 2013 Di Sd/Mi," As-Sibyan 2, no. 1 (2019): 21-38,

https://www.ejournal.stainupwr.ac.id/index.php/As_Sibyan/article/view/109\%0Ainternalpdf:/ /0.0.3.132/109.html.

${ }^{18}$ Hilda Taba, Curriculum Development Theory and Pratice, ed. Willard B. Spalding (Harcourt, Brace \& World, 1962).

19 E.G.Homrighausen and I.H.Enklaar, Pendidikan Agama Kristen.

${ }^{20}$ Ratag, "Pengembanganan Kurikulum Sekolah Minggu."

${ }^{21}$ Ika Widyasari Simanjuntak and Talizaro Tafonao, “Urgenitas Dalam Menerapkan Kurikulum Pendidikan Agama Kristen Bagi Orang Dewasa Di Gereja," Harati Jurnal Pendidikan Kristen 1, no. 1 (2021): 85-100. 


\begin{tabular}{|c|c|c|c|}
\hline MATERI & AKTIVITAS & WAKTU & KETERANGAN \\
\hline $\begin{array}{l}\text { Sejarah Perjanjian } \\
\text { Lama } \\
\begin{aligned} \text { - } & \text { Pembebasan } \\
& \text { bangsa Israel } \\
& \text { dari } \\
& \text { perbudakan } \\
- & \text { Perjalanan di } \\
& \text { padang gurun } \\
\text { - } & \text { Masuk ke } \\
& \text { tanah Kanaan } \\
\text { - } & \text { Dan lain-lain }\end{aligned}\end{array}$ & 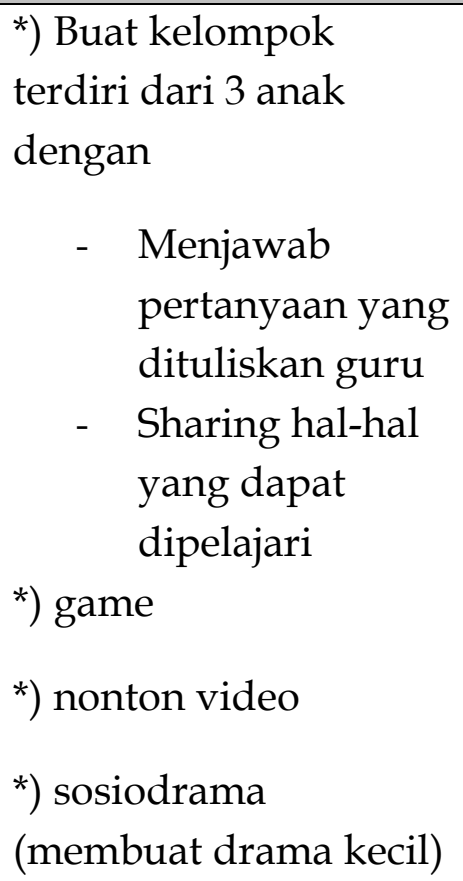 & 3 bulan & $\begin{array}{l}\text { Aktivitas sesuai } \\
\text { konteks anak madya } \\
\text { yaitu ada tantangan } \\
\text { untuk melakukan } \\
\text { sesuatu yang baru } \\
\text { termasuk saat } \\
\text { bekerjasama dengan } \\
\text { teman lain. Metode } \\
\text { menghafalkan ayat } \\
\text { hafalan sudah tidak } \\
\text { lagi mengena }\end{array}$ \\
\hline $\begin{array}{l}\text { Sejarah Perjanjian } \\
\text { Baru } \\
\begin{aligned} \text { - } & \text { Pelayanan } \\
& \text { Tuhan Yesus } \\
& \text { di bumi } \\
- & \text { Kenaikan } \\
& \text { Tuhan Yesus } \\
\text { - } & \text { Pentakosta } \\
\text { - } & \text { Gereja mula- } \\
& \text { mula } \\
\text { - } & \text { Kisah Para } \\
& \text { Rasul } \\
\text { - } & \text { Dan lain-lain }\end{aligned}\end{array}$ & $\begin{array}{l}\text { *) Buat kelompok } \\
\text { terdiri dari } 3 \text { anak } \\
\text { dengan } \\
\text { - Menjawab } \\
\text { pertanyaan yang } \\
\text { dituliskan guru } \\
\text { - Sharing hal-hal yang } \\
\text { dapat dipelajari } \\
\text { *) game } \\
\text { *) nonton video } \\
\text { *) sosiodrama } \\
\text { (membuat drama kecil) }\end{array}$ & 3 bulan & \\
\hline $\begin{array}{l}\text { Tokoh-tokoh Alkitab } \\
\begin{array}{c}\text { - Abraham } \\
\text { - } \text { Musa } \\
\text { - } \text { Sadrakh, } \\
\text { Mesakh dan } \\
\text { Abednego } \\
\text { - Paulus }\end{array}\end{array}$ & $\begin{array}{l}\text { *) Buat kelompok terdiri } \\
\text { dari } 3 \text { anak dengan } \\
\text { - Menjawab pertanyaan } \\
\text { yang dituliskan guru }\end{array}$ & 4 bulan & \\
\hline
\end{tabular}




\begin{tabular}{|c|c|c|c|}
\hline MATERI & AKTIVITAS & WAKTU & KETERANGAN \\
\hline - Dan lain-lain & $\begin{array}{l}\text { - Sharing hal-hal yang } \\
\text { dapat dipelajari } \\
\text { *) game } \\
\text { *) nonton video } \\
\text { *) sosiodrama } \\
\text { (membuat drama kecil) }\end{array}$ & & \\
\hline $\begin{array}{l}\text { Tema bebas dalam } \\
\text { konteks sesuai } \\
\text { dengan FT dan } \\
\text { kebutuhan anak } \\
\text { madya : } \\
\text { - } \text { Sejarah } \\
\text { berdirinya } \\
\text { gereja } \\
\text { setempat } \\
\text { - Keselamatan } \\
\text { - } \quad \text { Perkembangan } \\
\text { teknologi } \\
\text { - Isu-isu yang } \\
\text { ada di } \\
\text { masyakarat } \\
\text { saat itu } \\
\text { Belajar } \\
\text { bersaksi } \\
\text { Dan lain-lain }\end{array}$ & $\begin{array}{l}\text { *) Sharing kelompok } \\
\text { dipimpin guru } \\
\text { *) Kesaksian } \\
\text { *) Doa syafaat } \\
\text { *) Game } \\
\text { *) Penggunaan sosial } \\
\text { media dengan konten } \\
\text { kebenaran Firman } \\
\text { Tuhan seperti Tik Tok, } \\
\text { Instagram, Youtube, } \\
\text { Facebook, Twitter, dan } \\
\text { sebagainya }\end{array}$ & 2 bulan & $\begin{array}{l}\text { Materi ini diberikan } \\
\text { untuk membuka } \\
\text { wawasan baru bagi } \\
\text { anak madya dengan } \\
\text { dunia di sekeliling } \\
\text { mereka agar terus } \\
\text { berjalan memakai } \\
\text { kebenaran Firman } \\
\text { Tuhan dalam } \\
\text { merespon setiap } \\
\text { tantangan di luar. }\end{array}$ \\
\hline
\end{tabular}

Tabel 1. Contoh Kurikulum Kelas Madya

Semua materi pelajaran untuk kelas madya sudah bisa disusun berdasarkan kalender gereja agar dapat menyesuaikan dengan peristiwa-peristiwa yang akan diadakan di gereja seperti sejarah berdirinya gereja di tempat tersebut bisa dimasukkan ke dalam materi sekolah minggu agar anak madya melihat penyertaan Tuhan saat jemaat merindukan ada tempat ibadah sampai dengan gedung gereja berdiri. 


\section{Peran guru sekolah minggu}

Guru sekolah minggu mempunyai peranan penting di dalam melaksanakan kurikulum sekolah minggu karena guru adalah pelaksana pada saat pembelajaran berlangsung. Guru di dalam pandangan masyarakat adalah orang yang melaksanakan pendidikan di sekolah, sebenarnya guru bisa melakukan pendidikan baik di tempat formal seperti sekolah namun bisa di manapun juga baik di rumah, gereja dan tempat yang tepat untuk mengajar. Menurut Sriyanti Esen guru merupakan pendidik yang memiliki peranan penting dalam membentuk anak menjadi pribadi yang dewasa serta dalam pendidikan. Sedangkan menurut pendapat Djamarah orang yang memberikan ilmu pengetahuan kepada anak didik adalah guru. ${ }^{22}$

Homrighausen menjelaskan bahwa Guru Kristen adalah Pertama-tama, menjadi penafsir iman Kristen, artinya guru yang menguraikan dan menerangkan kepercayaan Kristen itu, karena diharuskan menyampaikan harta- harta dari masa lampau kepada para pemuda yang akan menempuh masa depan. Kedua, guru juga menjadi gembala bagi murid-muridnya. Guru bertanggung jawab atas hidup rohani anak, dan wajib membina dan memajukan hidup rohani itu. Ketiga, guru harus menjadi pemimpin, artinya tidak menuntun setiap anak- anak untuk masuk ke kepercayaan Kristen dengan paksa, melainkan harus membimbing anak secara pelan dan halus kepada Juruselamat yang hidup. Guru harus menjadi teladan dan mencerminkan roh Kristus dalam seluruh pribadinya. Dan yang Keempat, guru harus menjadi seorang penginjil, artinya bertanggung jawab atas penyerahan diri setiap para peserta didik atau anak- anak usia dini kepada Yesus Kristus. Karena tujuan adalah supaya setiap anak dapat sungguh- sungguh menjadi murid- murid Tuhan Yesus. Guru juga tak boleh puas sebelum anak didiknya menjadi orang Kristen yang sejati. ${ }^{23}$ Selanjutnya menjadi tanggung jawab guru sebagai pendidik untuk memperkenalkan Kristus dalam kehidupan setiap siswa. ${ }^{24}$

Sesuai dengan penjelasan di atas dan hakekat Sekolah Minggu, guru sekolah minggu terutama guru madya harus memiliki kriteria sebagai berikut :

${ }^{22}$ Sriyanti and Nakamnanu, “Peran Guru Dalam Menerapkan Pendidikan Agama Kristen Untuk Menumbuhkan Iman Kristen Anak Sejak Dini."

${ }^{23}$ E.G.Homrighausen and I.H.Enklaar, Pendidikan Agama Kristen.

${ }^{24}$ Edulead Volume, "108 EDULEAD Volume 1 Edisi 1" 1 (2012): 108-113. 


\begin{tabular}{|c|c|c|}
\hline KRITERIA & KETERANGAN & $\begin{array}{c}\text { HAL YANG HARUS } \\
\text { DILAKUKAN }\end{array}$ \\
\hline Lahir baru & $\begin{array}{l}\text { Mengakui Yesus } \\
\text { sebagai Juru Selamat } \\
\text { Mengasihi Tuhan }\end{array}$ & $\begin{array}{l}\text { - Memiliki hubungan } \\
\text { pribadi dengan } \\
\text { Tuhan (HPDT) } \\
\text { - } \quad \text { Membaca Firman } \\
\text { Tuhan setiap hari } \\
\text { - } \quad \text { Setia melayani }\end{array}$ \\
\hline $\begin{array}{l}\text { Hati untuk } \\
\text { pelayanan anak }\end{array}$ & $\begin{array}{l}\text { Sayang kepada anak- } \\
\text { anak }\end{array}$ & 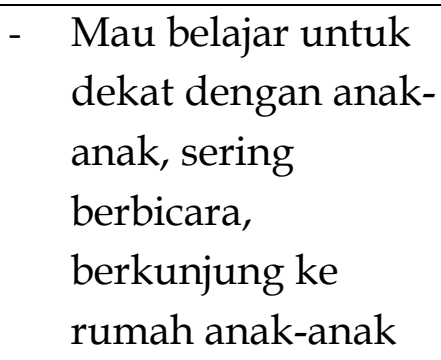 \\
\hline Kreatif & $\begin{array}{l}\text { Cara mengajar dengan } \\
\text { kreatif dan menarik }\end{array}$ & $\begin{array}{l}\text { - } \text { Belajar dari } \\
\text { Youtube atau } \\
\text { sumber lain yang } \\
\text { dapat } \\
\text { dipertanggung- } \\
\text { jawabkan }\end{array}$ \\
\hline Mentor & $\begin{array}{l}\text { Memahami karakter } \\
\text { setiap anak } \\
\text { Menjadi teman curhat }\end{array}$ & 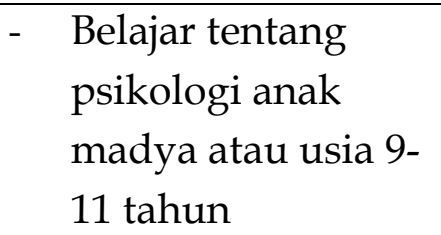 \\
\hline
\end{tabular}

Tabel 2. Kriteria guru sekolah minggu

Dengan adanya kurikulum bagi anak madya yang sudah disusun dan peran guru Sekolah Minggu yang sesuai dengan kriteria bagi anak madya tujuan dari Sekolah Minggu dapat tercapai yaitu membawa anak-anak ini dalam pengenalan akan Tuhan dan mereka menjadi manusia yang mencintai Tuhan sejak masih kecil sampai dewasa.

\section{Kesimpulan}

Berdasarkan kajian dalam artikel ini, penulis hendak mengatakan bahwa kurikulum pendidikan agama Kristen di dalam gereja tidak boleh diabaikan. Sebab melalu sekolah minggu kelas madya menjadi wadah dalam memberitakan Injil kepada anak-anak. Sesuai dengan tujuan dalam penulisan artikel ini yaitu mendorong gereja dan guru untuk mempersiapkan kurikulum yang sesuai dengan karakteristik anak kelas madya. Gereja dan guru memiliki peran penting dalam mengajarkan 
pendidikan agama Kristen dengan menggunakan berbagai literatur yang berhubungan dengan setiap topik yang diajarkan kepada anak-anak di gereja. Tetapi ironisnya masih ditemukan beberapa kendala yang dihadapi oleh gereja dan guru dalam mempersiapkan kurikulum. Salah satunya yaitu keserius gereja dalam memperhatikan kurikulum tersebut masih kurang maksimal. Oleh karena itu melalui tulisan hendak menjadi sumbangsih pemikiran baru bagi para pelayan dan guru untuk memperperhatikan kurikulum berdasarkan kebutuhan anak. Selain tulisan ini menjadi kontribusi baru bagi para peneliti berikutnya dalam melanjutkan penelitian ini.

\section{Rujukan}

E.G.Homrighausen, and I.H.Enklaar. Pendidikan Agama Kristen. 9th ed. Kwitang, Jakarta: BPK Gunung Mulia, 1987.

Karnawati, Karnawati, and Ayin Claudia. "Model Desain Kurikulum Pewartaan Injil Untuk Anak Usia Dini Di Sekolah Minggu Rumah." Integritas: Jurnal Teologi 3, no. 1 (2021): 201-212.

Muliawan, Jasa Ungguh. Metodologi Penelitian Pendidikan. Cetakan I,. Yogyakarta: Penertbit Gava Media, 2014.

Nafi'ah, Siti Anisatun. “Model Pengembangan Kurikulum Hilda Taba Pada

Kurikulum 2013 Di Sd/Mi." As-Sibyan 2, no. 1 (2019): 21-38.

https://www.ejournal.stainupwr.ac.id/index.php/As_Sibyan/article/view/10 9\%0Ainternal-pdf:/ /0.0.3.132/109.html.

Pattinama, Yenny Anita. "Peranan Sekolah Minggu Dalam Pertumbuhan Gereja." SCRIPTA: Jurnal Teologi dan Pelayanan Kontekstual 8, no. 2 (2020): 132-151.

Perdana, Novrian Satria. "Implementasi Peranan Ekosistem Pendidikan Dalam Penguatan Pendidikan Karakter Peserta Didik." Refleksi Edukatika : Jurnal Ilmiah Kependidikan 8, no. 2 (2018): 183-191.

Ratag, Adolf Edwin. "Pengembanganan Kurikulum Sekolah Minggu." LOGON ZOES: Jurnal Teologi, Sosial dan Budaya 1, no. 1 (2017): 1-17.

Simanjuntak, Ika Widyasari, and Talizaro Tafonao. "Urgenitas Dalam Menerapkan Kurikulum Pendidikan Agama Kristen Bagi Orang Dewasa Di Gereja." Harati Jurnal Pendidikan Kristen 1, no. 1 (2021): 85-100.

Sriyanti, and Esen Hon Nakamnanu. "Peran Guru Dalam Menerapkan Pendidikan Agama Kristen Untuk Menumbuhkan Iman Kristen Anak Sejak Dini." Shamayim 1, no. 1 (2020).

Taba, Hilda. Curriculum Development Theory and Pratice. Edited by Willard B. Spalding. Harcourt, Brace \& World, 1962.

Tafonao, Talizaro. “Peran Pengajaran Pendidikan Agama Kristen Dalam Keluarga

Sangat Penting Untuk Diajarkan Kepada Anak-Anak, Baik Dalam Keluarga, Sekolah, Di Tempat Ibadah Dan Masyarakat, Agar Kelak Anak-Anak Dapat Menghadapi Setiap Problem Secara Kognitif, Afektif Dan Psik." Edudikara: Jurnal Pendidikan dan Pembelajaran 3, no. 2 (2018): 125.

Tafonao, Talizaro, and Prasetyo Yuliyanto. “Peran Pendidikan Agama Kristen Dalam 
Memerangi Berita Hoaks Di Media Sosial." Jurnal Ilmiah Religiosity Entity Humanity (JIREH) 2, no. 1 (2020): 1-12.

Volume, Edulead. "108 EDULEAD Volume 1 Edisi 1" 1 (2012): 108-113.

Wijanarko Utomo. "CIRI KHAS PERKEMBANGAN ANAK USIA 9-11 TAHUN."

Children Cafe. Last modified 2018. Accessed May 25, 2021.

https://www.childrencafe.com/ciri-khas-perkembangan-anak-usia-9-11tahun/\#: :text=Kini mereka tidak terlalu suka,serta gemar akan berbagai bacaan.

“Hakekat Sekolah Minggu." Alkitab Sabda. Accessed May 29, 2021. https://alkitab.sabda.org/.

“Robert Raikers." Wikipedia. Accessed October 30, 2021. https://id.wikipedia.org/wiki/Robert_Raikes. 